\title{
THE CLINICAL VALUE OF URINARY 17-KETOGENIC STEROID DETERMINATIONS
}

\author{
BY \\ M. J. LEVELl, F. L. MITCHELL, C. G. PAINE, AND ARTHUR JORDAN \\ From the Royal Infirmary, Sheffield, and the Jessop Hospital for Women, Sheffield
}

(RECEIVED FOR PUBLICATION MARCH 20, 1956)

During recent years increasing importance has been attached to the study of adrenal cortical hormones, and consequently much work has been directed towards utilizing the daily output of these hormones and their metabolites in urine as an index of adrenocortical function. Hydrolysis of the conjugated forms in which the steroids are present in urine is a necessary preliminary to their extraction and estimation, but the two common methods of hydrolysis-by mineral acid and by $\beta$-glucuronidase-are not entirely satisfactory, the former causing destruction or alteration of a large proportion of the cortical steroids, the latter not being sufficiently quantitative (Bayliss, 1952).

Norymberski and his colleagues (Brooks and Norymberski, 1953 ; Norymberski, Stubbs, and West, 1953) have obviated the difficulties of hydrolysis by a technique in which the side chain on $\mathrm{C}_{(17)}$ is oxidized to a ketone group before hydrolysis, the more stable 17-ketosteroids thus formed being hydrolysed by acid and estimated by one of the established methods. As far as is known, all the important cortical steroids containing a hydroxyl group at $C_{(17)}$, with the exception of 17-hydroxy-20-oxosteroids unsubstituted at $\mathrm{C}_{(21)}$, are estimated by this means. It seems probable that this group of steroids, the 17-ketogenic steroids, gives a measurement of the adrenal function concerned with the production of $17 \alpha$ hydroxycorticosterone (hydrocortisone, Kendall's compound $F$ ) which has been shown by Bush and Sandberg (1953) to be the major cortical steroid in human blood.

For three years the technique has been used as a routine method of estimation. It has proved to be satisfactory and to give reproducible results. Out of a total of some 3,000 assays, 600 , carried out on 400 different patients, were selected as a basis for discussing the clinical utility of the estimation. The cases studied were grouped into those suffering from disorders in which it was known that adrenal cortical dysfunction plays a leading role, and those in which the adrenal may be in- N directly affected. Diagnoses were made primarily on clinical evidence.*

\section{Methods}

17-Ketosteroids and 17-Ketogenic Steroids.-The method used was that of Norymberski et al. (1953). with the modification of Gibson and Norymberski (1954). Each of the estimations was performed in duplicate. From the difference between duplicate readings of a random series of 170 assays with values within the normal range, the standard error of a single duplicate determination was found to be $0.7 \mathrm{mg}$./da! in the case of 17 -ketosteroids and $1.9 \mathrm{mg}$./ day in the case of 17-ketogenic steroids.

Glucose in the urine interferes with the estimation, as was pointed out by Norymberski et al. (1953). All urines were tested before assay and any glucose was removed by suspending 1-2 g. of baker's yeast. washed with water, in $7.0 \mathrm{mi}$. of urine in a graduated centrifuge tube. After standing overnight at room temperature, the total volume was noted $(x \mathrm{ml}$.), and the suspension was centrifuged at 4.000 r.p.m. for five minutes. Portions of the supernatant $(2.0 \mathrm{ml}$.) were taken for the bismuthate oxidation. Multiplication by the factor $\frac{x}{7}$ corrected the final results for the change in urine volume due to the addition of the yeast.

Urinary gonadotrophins were assayed by the method of Levin and Tyndale (1937). The total free and combined urinary oestrogens were estimated by the mouse vaginal smear technique.

\section{Results}

Establishment of Normal Daily Excretion of 17-Ketogenic Steroids.-Assays carried out on 83 normal females (ages 3-101 years) and 99 normal males (ages 6-90 years) are shown graphically together with the corresponding 17-ketosteroid assays in Figs. 1 and 2.

The values show a rise during childhood, the two series having apparently identical ranges up

* Some of these patients have been the subject of a resent publication (Hubble, 1955), and we are grateful to Dr. Hubble for permission to include them in this survey. 


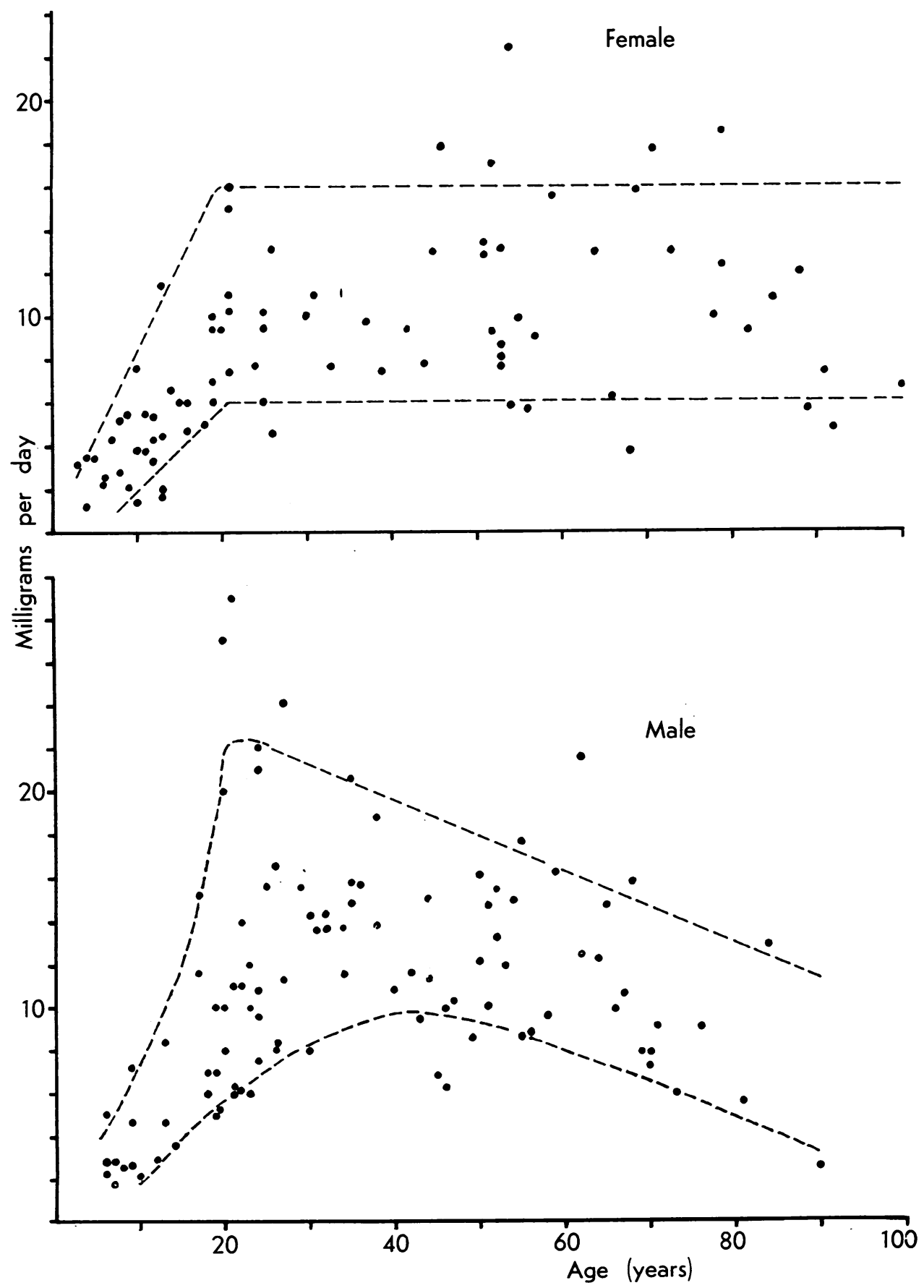

FIG. 1.-The 17-ketogenic steroid excretion in a series of normal males and females. Lines have been drawn to include $80 \%$ of the points, and are referred to in the text. 

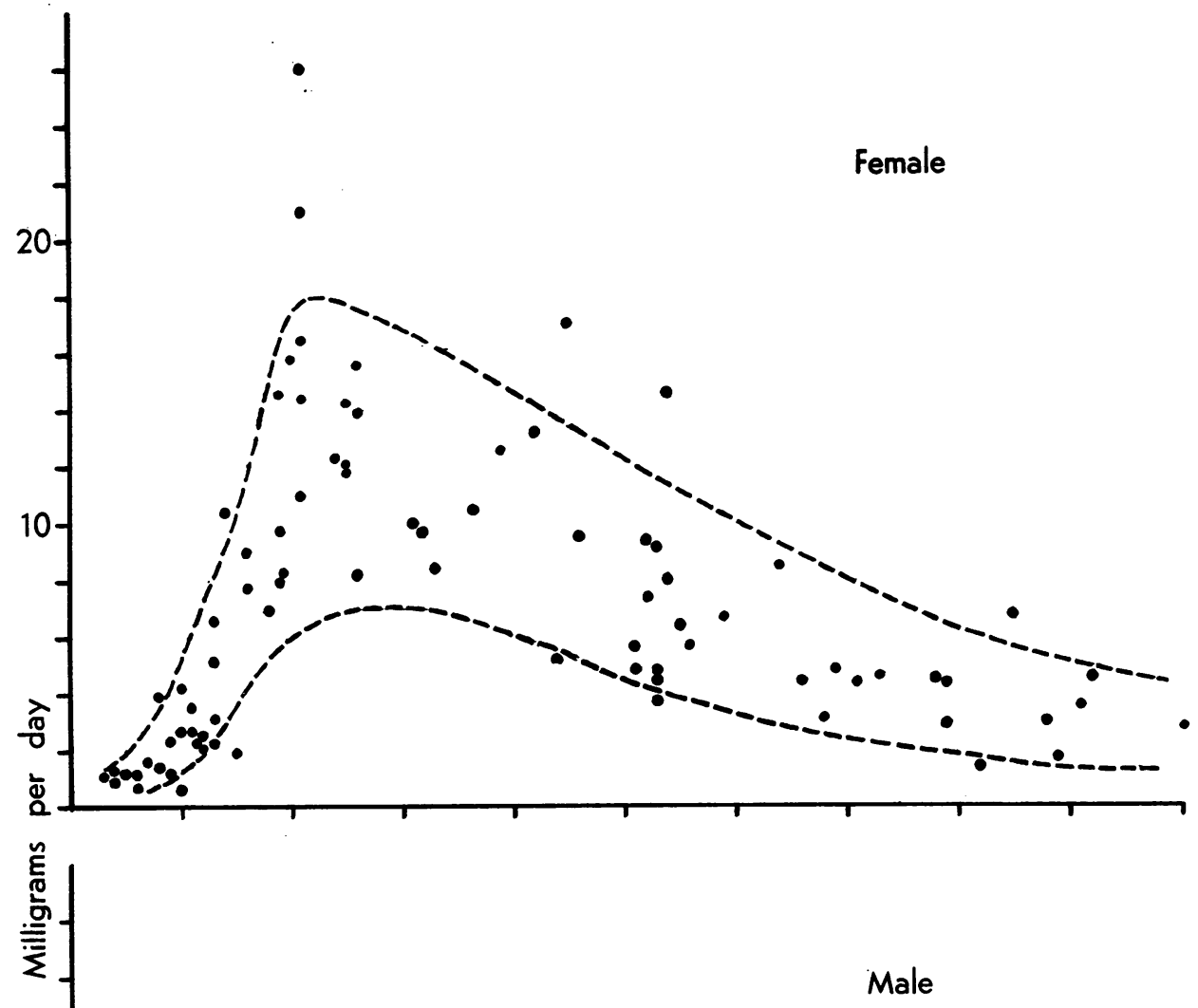

Fio. 2.-The 17-ketosteroid excretion in the same series of normal males and females as shown in Fig. 1. Lines have been drawn to include $80 \%$ of the points. 
TABLE I

CASES OF SUSPECTED ADDISON'S DISEASE

\begin{tabular}{|c|c|c|c|c|c|c|c|c|c|c|}
\hline \multirow[b]{2}{*}{ Case } & \multirow[b]{2}{*}{ Sex } & \multirow[b]{2}{*}{ Age } & \multicolumn{2}{|c|}{ Before A.C.T.H.* } & \multicolumn{2}{|c|}{ On A.C.T.H.* } & \multirow[b]{2}{*}{$\begin{array}{l}\text { Duration } \\
\text { of } \\
\text { A.C.T.H. } \\
\text { Therapy } \\
\text { (Days) }\end{array}$} & \multirow[b]{2}{*}{$\begin{array}{l}\text { A.C.T.H. } \\
\text { Dose } \\
\text { (mg. } \times \\
\text { No. of } \\
\text { Doses) }\end{array}$} & \multirow[b]{2}{*}{ Route } & \multirow[b]{2}{*}{ Final Diagnosis } \\
\hline & & & $\begin{array}{c}17- \\
\text { Keto- } \\
\text { steroids } \\
\text { (mg./day) }\end{array}$ & $\begin{array}{l}17- \\
\text { Ketogenic } \\
\text { Steroids } \\
\text { (mg./day) }\end{array}$ & $\begin{array}{c}17- \\
\text { Keto- } \\
\text { steroids } \\
\text { (mg./day) }\end{array}$ & $\begin{array}{c}17- \\
\text { Ketogenic } \\
\text { Steroids } \\
\text { (mg./day) }\end{array}$ & & & & \\
\hline $\begin{array}{l}\text { A } \\
\mathbf{B} \\
\mathbf{C} \\
\mathbf{D} \\
\mathbf{E} \\
\mathrm{F} \\
\mathrm{G} \\
\mathbf{H} \\
\mathbf{J} \\
\mathbf{K} \\
\mathbf{L}\end{array}$ & $\begin{array}{l}\mathbf{M} \\
\mathbf{F} \\
\mathbf{F} \\
\mathbf{F} \\
\mathbf{F} \\
\mathbf{F} \\
\mathbf{F} \\
\mathbf{F} \\
\mathbf{M} \\
\mathbf{F} \\
\mathbf{F}\end{array}$ & $\begin{array}{l}42 \\
50 \\
66 \\
60 \\
50 \\
22 \\
23 \\
41 \\
46 \\
44 \\
21\end{array}$ & $\begin{array}{l}6 \\
2 \\
3 \\
4 \\
5 \\
5 \\
9 \\
7 \\
3 \\
8 \\
1\end{array}$ & $\left.\begin{array}{r}7 \\
2 \\
6 \\
6 \\
17 \\
7 \\
8 \\
6 \\
2 \\
6 \\
3\end{array}\right\}$ & $\begin{array}{r}5 \\
1 \\
4 \\
11 \\
9 \\
22 \\
28 \\
10 \\
\text { No test pe }\end{array}$ & $\begin{array}{r}7 \\
1 \\
6 \\
27 \\
53 \\
39 \\
52 \\
15 \\
\\
\text { formed }\end{array}$ & $\begin{array}{l}2 \\
2 \\
2 \\
1 \\
2 \\
2 \\
2 \\
1\end{array}$ & $\begin{array}{l}25 \times 8 \\
25 \times 2 \\
40 \times 4 \\
25 \times 4 \\
40 \times 2 \\
25 \times 2 \\
25 \times 2 \\
15 \times 1\end{array}$ & $\begin{array}{l}\text { I.M. } \\
\text { I.V. } \\
\text { I.M. } \\
\text { I.M. } \\
\text { I.V. } \\
\text { I.V. } \\
\text { I.V. } \\
\text { I.V. }\end{array}$ & $\begin{array}{l}\text { Addison's disease } \\
\qquad, ", ", \\
\text { Pellagra ", } \\
\text { Pigmentation, no cause found } \\
\text { Anaemia } \\
\text { Anorexia nervosa } \\
\text { Anaemia, pregnant } \\
\text { Addison's disease with diabetes } \\
\text { ? }\end{array}$ \\
\hline
\end{tabular}

* Average values obtained before and during corticotrophin administration. I.M. Intramuscular injection. I.V. Intravenous infusion over six to eight hours of the 24-hour period of urine collection.

to the age of 15 years, after which the males rise to a higher average than the females. Between the ages of 20 and 40 years the male geometric mean, $12.0 \mathrm{mg}$./day, is significantly higher than the female geometric mean, $9.3 \mathrm{mg}$./ day $(P=0.05)$, results in broad agreement with those of Diczfalusy, Plantin, Birke, and Westman (1955) and of Schüller (1956). At any age the values for either sex seem to be better represented by a lognormal distribution than by a normal one and for this reason the geometric means are given.

In later life the excretion of 17-ketogenic steroids in the men appears to decline. The values for the women do not show a similar decline. The limits drawn on the figures include approximately $80 \%$ of the observations to the exclusion of the highest $10 \%$ and the lowest $10 \%$. These limits suggest a difference between the two sexes in the relationship of age to rate of excretion. There seems no reason to doubt the validity of the indicated trends in childhood, but in adult life the relatively small number of points in any age group makes the limits tentative; in particular it must be emphasized that in the females a regression with age is not excluded by these observations and, in fact, Schüller (1956) found such a regression. The limits give what at present appears to be the most convenient representation of the normal range and are intended to facilitate comparison with values found in pathological conditions.

Two normal persons on whom 17-ketogenic steroids were assayed on six consecutive days gave values in mg./day of $6.6,10.4,7.6,7.3,6.4$, and 9.1 in one case, and $8.6,8.4,8.8,7.8,5.0$, and 4.7 in the other.

The 17-ketogenic steroid excretion of two normal women has been assayed throughout the menstrual cycle; neither case showed any cyclic variation.

In Addison's Disease. - Of 11 cases in which Addison's disease was suspected, six had values for 17-ketosteroids and 17-ketogenic steroids within the normal ranges, and five had low values.

In eight of the cases, the effect of corticotrophin administration on the excretion of both groups of steroids was measured. Table I shows that five cases $(\mathrm{D}, \mathrm{E}, \mathrm{F}, \mathrm{G}$, and $\mathrm{H})$ gave a positive response, and were shown subsequently not to be cases of Addison's disease. The other three cases showed no response.

The results found in patients $\mathrm{E}$ and $\mathrm{H}$ show the advantage of the 17-ketogenic steroid assay over that of 17-ketosteroids as an indication of response to corticotrophin stimulation; the 17ketogenic steroids rise from 17 and $6 \mathrm{mg}$./ day to 53 and $15 \mathrm{mg}$./day respectively, whereas the 17-ketosteroids rise only from 5 and 7 to 9 and $10 \mathrm{mg}$./day respectively, changes which without additional evidence might be ascribed to chance day-to-day variation.

This small response of the 17-ketosteroid excretion to corticotrophin stimulation agrees with the findings of Hernberg and Lamberg (1955).

In Myxoedema and Hypopituitarism.-Statland and Lerman (1950) and Hill, Reiss, Forsham, and Thorn (1950) showed that adrenal cortical function is often depressed in cases of myxoedema, and Table II shows that both 17-ketosteroids and 17-ketogenic steroids are considerably lowered in this condition. This lowering is possibly due to the effect of the lack of thyroid hormone on the pituitary or adrenal cortex. It was found by Hill et al. (1950) and by Statland and Lerman (1950) 
TABLE II

CASES OF HYPOTHYROIDISM AND HYPOPITUITARISM

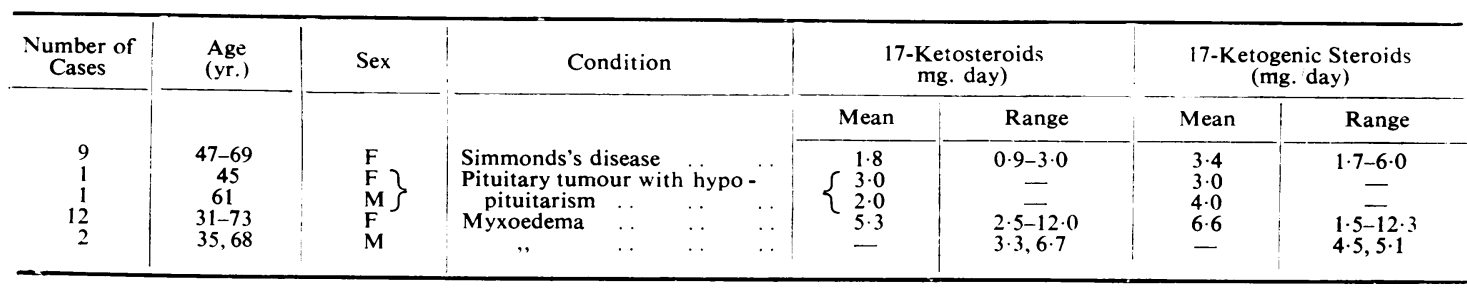

TABLE III

CASES SHOWING CLINICAL MANIFESTATIONS OF CUSHING'S SYNDROME

\begin{tabular}{|c|c|c|c|c|c|c|c|c|c|c|c|}
\hline Case & Sex & $\begin{array}{r}\text { Age } \\
(\mathrm{yr} .)\end{array}$ & $\begin{array}{l}\text { 17-Keto- } \\
\text { steroids } \\
\text { (mg. day) }\end{array}$ & $\begin{array}{c}\text { 17-Keto- } \\
\text { genic } \\
\text { Steroids } \\
\text { (mg. day) }\end{array}$ & Obesity & Hirsutes & $\begin{array}{l}\text { Amenor- } \\
\text { rhoea }\end{array}$ & Diabetes & $\begin{array}{l}\text { Hyper- } \\
\text { tension }\end{array}$ & $\begin{array}{l}\text { Osteo- } \\
\text { porosis }\end{array}$ & Striae \\
\hline $\begin{array}{l}\mathbf{M} \\
\mathbf{N} \\
\mathbf{O} \\
\mathbf{P} \\
\mathbf{Q} \\
\mathbf{R} \\
\mathbf{S}\end{array}$ & $\begin{array}{l}\mathbf{F} \\
\mathbf{F} \\
\mathbf{F} \\
\mathbf{F} \\
\mathbf{F} \\
\mathbf{F} \\
\mathbf{F}\end{array}$ & $\begin{array}{l}24 \\
19 \\
47 \\
13 \\
35 \\
57 \\
50\end{array}$ & $\begin{array}{r}23 \\
40 \\
4 \\
9 \\
20 \\
8 \\
19\end{array}$ & $\begin{array}{r}34 \\
29 \\
6 \\
15 \\
32 \\
10 \\
24\end{array}$ & $\begin{array}{l}- \\
\overline{-} \\
\dot{-} \\
+ \\
+ \\
+\end{array}$ & $\begin{array}{l}- \\
+ \\
- \\
+ \\
+\end{array}$ & $\begin{array}{l}+ \\
* \\
+ \\
+ \\
+ \\
+\end{array}$ & $\begin{array}{c}\cdots \\
+ \\
- \\
- \\
-\end{array}$ & $\begin{array}{l}+ \\
+ \\
+ \\
+ \\
+ \\
+ \\
+\end{array}$ & $\begin{array}{l}- \\
- \\
- \\
\pm \\
\cdots\end{array}$ & $\begin{array}{l}- \\
- \\
- \\
\div \\
+ \\
-\end{array}$ \\
\hline
\end{tabular}

that thyroid extract therapy usually increased the urinary excretion of 17-ketosteroids. Hubble (1955) showed that the excretion of 17-ketogenic steroids behaves similarly, but the increase is more marked.

In the cases of hypopituitarism, values were in general lower than in myxoedema (Table II), but the ranges of values given by the two conditions show too great an overlap for the assay to be of much assistance in differentiating the two conditions.

In Cushing's Syndrome.-Owing to the rarity of this condition, very few cases showing the full syndrome have been available for study. Table III shows seven cases of almost complete Cushing's syndrome with a summary of their clinical findings.

In Hirsutes. - A group was selected of 26 women showing various degrees of hirsutes without other complications: a further eight gave a history of amenorrhoea or oligomenorrhoea. Neither group contained cases showing other indications of Cushing's syndrome. The 17-ketogenic steroids of both groups showed no gross deviation from normal. Three values fell below the $80 \%$ limits $(4$, 4 , and $5 \mathrm{mg}$./day) and eight values above these limits (up to $22 \mathrm{mg}$./day). The 17-ketosteroids tended to be raised, and ranged from 5 to $30 \mathrm{mg}$./ day, 12 of the values being above the $80 \%$ normal limit. The two groups of cases showed no difference in the distribution of values.
One hirsute patient was studied throughout a menstrual cycle and showed a cyclic variation in 17 -ketosteroid excretion $(10 \mathrm{mg}$./day in mid-cycle and $28 \mathrm{mg}$./day at the start of bleeding), but there was no corresponding variation in 17 -ketogenic steroid output.

In Precocious Puberty and Virilism.-Table IV shows the level of excretion in several cases of the adrenogenital syndrome.

TABLE IV

CASES OF PRECOCIOUS PUBERTY AND VIRILIS M

\begin{tabular}{|c|c|c|c|c|c|c|}
\hline Cass & Sex & $\begin{array}{l}\text { Age } \\
(\mathrm{yr} .)\end{array}$ & \begin{tabular}{|}
$17-$ \\
Keto- \\
steroids \\
(mg. \\
day)
\end{tabular} & \begin{tabular}{|c}
$17-$ \\
Keto- \\
genic \\
Steroids \\
(mg. \\
day)
\end{tabular} & Condition & Remarks \\
\hline $\mathrm{T}$ & M & 14 & 99 & 129 & $\begin{array}{l}\text { Precocious } \\
\text { puberty }\end{array}$ & 1 adrenal re- \\
\hline $\mathrm{U}$ & $\mathbf{M}$ & 4 & 28 & 44 & ," & $\begin{array}{l}\text { yr. } \\
\text { Testes } \\
\text { undescended }\end{array}$ \\
\hline V & $F$ & 3 & 9 & 29 & $\begin{array}{l}\text { Pseudoherm- } \\
\text { aphrodite }\end{array}$ & \\
\hline $\begin{array}{l}\text { W } \\
\text { X } \\
\text { Y }\end{array}$ & $\begin{array}{l}F \\
F \\
F\end{array}$ & $\begin{array}{r}3 \\
2 \\
38\end{array}$ & $\begin{array}{l}20 \\
12 \\
70\end{array}$ & $\begin{array}{r}18 \\
37 \\
100\end{array}$ & Virilism & \\
\hline
\end{tabular}

In all these cases oral cortisone therapy produced a lowering of 17-ketosteroid excretion.

In Thyrotoxicosis and Diabetes. $-A$ number of patients were studied while suffering from one or both of these diseases, and, except when the two conditions were coincident, no systematic devia- 

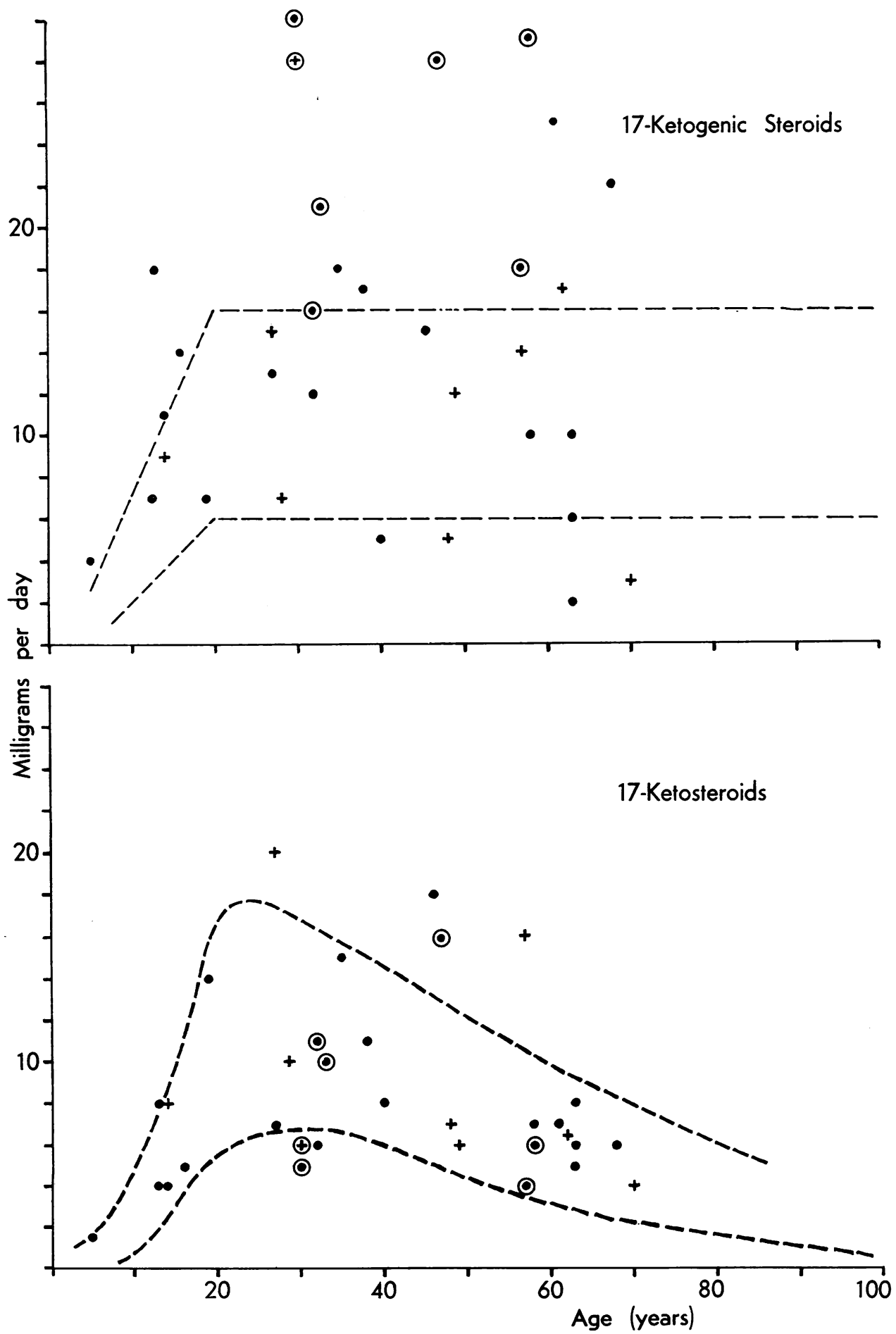

Fig. 3.-Steroid excretion in cases of diabetes. Female, + Male; $\oplus$ and $\odot$ cases showing thyrotoxicosis also. The lines depicting the average normal limits have been transferred from Figs. 1 (female) and 2 (female). 
tion from normal excretion values could be demonstrated.

Of 32 patients suffering only from thyrotoxicosis, three cases had a 17-ketogenic steroid output above $20 \mathrm{mg}$./day $(24,24$, and $30 \mathrm{mg}$.) ; in only one case was the 17-ketosteroid value abnormally high (female aged 30:24 mg./day ; 17-ketogenic steroids $18 \mathrm{mg}$./day).

The values found in diabetes and in coincident diabetes and thyrotoxicosis are shown in Fig. 3. The high 17-ketogenic steroid levels found in the cases showing both conditions support the hypothesis of Hubble (1955) that hyperpituitarism is the underlying lesion in such cases.

In Amenorrhoea.-There were 33 cases of primary and secondary amenorrhoea in which no other endocrine disorder was obvious. Both the urinary oestrogen output and the urinary gonadotrophin output were low (oestrogen less than 15 i.u./ day and gonadotrophin less than 5 mouse-units/ day) in 13 cases: in one of these, aged 32 , the output of 17-ketogenic steroids was $21 \mathrm{mg}$./day (17ketosteroids $10 \mathrm{mg}$./day); the values in the remaining cases were normal. Three patients had low urinary oestrogen outputs (below 15 i.u./day) and normal urinary gonadotrophin outputs (above 5 mouse-units/day): all had normal steroid excretions. The remaining 17 cases had normal urinary gonadotrophin outputs and normal urinary oestrogen outputs ( 20 to 160 i.u./day); the outputs of 17-ketogenic steroids showed rather a wide scatter, with a range of 2.5 to $22 \mathrm{mg}$./ day, two being below and 14 being above the $80 \%$ limits.

In Gynaecomastia.-Of five cases of gynaecomastia studied (aged 14-42 years), three were normal; one (aged 17 years: 17-ketosteroids 16 mg./day; 17-ketogenic steroids $26 \mathrm{mg}$./day) showed a slightly raised, and one (aged 14 years: 17-ketosteroids $2 \mathrm{mg}$./day; 17-ketogenic steroids $7 \mathrm{mg}$./day) showed slightly lowered steroid outputs. The urinary oestrogen level in four of these cases was within the normal range for men: the fifth case was not assayed. The findings for 17ketosteroids and oestrogens agree with those of Peters, Sieber, and Davis (1955).

In Rheumatoid Arthritis.-In 29 cases of rheumatoid arthritis ( 21 females aged 19-83 years ; 9 males aged 30-70 years) the 17-ketogenic steroid values showed no departure from normal. This is in disagreement with the results of Norymberski et al. (1953), who reported considerably lowered values in this condition. The 17 -ketosteroids were found to be slightly low, being around the lower limit of normal.
In Obesity. - In 46 cases of obesity ( 30 females aged 8-65 years; 16 males aged $10-50$ years) both the 17-ketogenic steroid and 17-ketosteroid values did not differ significantly from the normal, though both tended towards the upper limits.

\section{General Discussion}

The normal values observed in some cases of Addison's disease and of Cushing's syndrome, and the unexpectedly high values found for adrenal steroids in some cases of pituitary insufficiency, illustrate clearly the dangers of placing too much reliance on single determinations.

The limits of the normal range are wide, so that a person's 17-ketogenic steroid excretion may vary considerably without reaching a value which would be regarded as abnormal. In this respect, the status of the 17-ketogenic steroid assay is similar to that of the $17-$ ketosteroid estimation. These observations emphasize the desirability of performing an adrenal function test wherever indicated. Thorn (1953) has discussed the application of stimulation of the adrenals by corticotrophin to the diagnosis of Addison's disease and of hypopituitarism, and Eik-Nes, Sandberg, Migeon, Tyler, and Samuels (1955) have shown that adrenal capacity can be estimated by following the level of plasma 17-hydroxycorticosteroids during corticotrophin stimulation. The results presented here and those of Hubble (1955) show that the 17-ketogenic steroid assay provides a satisfactory index of such stimulation, and moreover is much more suitable for routine use than the techniques of Eik-Nes et al. (1955).

The very high values found in the patients with virilizing adrenal hyperplasias are in accordance with the theory of Jailer (1953), who postulated a block in the biosynthesis of compound $F$ with consequent overproduction of the precursor, 17hydroxyprogesterone. As this substance does not adequately suppress the pituitary production of adrenocorticotrophic hormone, the effect is to produce adrenal hyperplasia, and although 17 hydroxyprogesterone is not in itself ketogenic it is probably converted in part to a 17-ketogenic steroid with a $17: 20$-diol side chain. In the cases of hirsutes cited, the 17-ketogenic steroid values were generally within the normal range, which accords with the common view that patients with hirsutes even with amenorrhoea are not usually suffering from adrenal virilism.

The potentialities of the 17-ketogenic steroid assay in diagnosis and control of treatment are best studied by comparison with the 17-ketosteroid assay. In most of the conditions considered, as far 
as single estimations are concerned, the two methods yield about the same amount of information as judged by the extent of the departure from normal. In suspected cases of the adrenogenital syndrome it is advantageous to have both assays performed, but in general it would seem that one would suffice. In view of the undoubted advantage of the 17-ketogenic steroid assay in following changes in adrenal function, as evidenced by corticotrophin tests, by treatment of cases of hypothyroidism (Hubble, 1955), and by response to stress (Jepson, Jordan, and Levell, 1956), this is the assay of choice.

The technique involves, of necessity, the estimation of 17-ketosteroids as a part of the 17-ketogenic steroid assay. Appleby, Gibson, Norymberski, and Stubbs (1955) have recently elaborated a technique for assaying urinary corticosteroids based on the principle of the 17-ketogenic steroid assay but not involving an estimation of the 17 . ketosteroids. The results obtained appear to be similar except in cases of the adrenogenital syndrome (Appleby et al., 1955). This assay, embracing as it does, a larger group of adrenal steroids, may be more efficient than the assay used here for estimating adrenal function.

\section{Summary}

The normal range of urinary 17-ketogenic steroids has been established from assays on 182 persons aged from 3 to 101 years.

Values found in the following conditions are presented: Addison's disease, myxoedema, hypopituitarism, Cushing's syndrome, the adrenogenital syndrome, hirsutes, diabetes, thyrotoxicosis, amenorrhoea, rheumatoid arthritis, and obesity.
The relative utility of the 17-ketogenic steroid assay and the 17-ketosteroid assay is discussed, and the greater value of the former in corticotrophin tests is demonstrated.

We wish to thank the consultants of the United Sheffield Hospitals and the Sheffield Region, who have allowed us to publish details of their patients, and Dr. J. K. Norymberski for some of the normal values and for providing us with details of the assay method before publication. We are indebted to Miss R. A. Leonard, Mrs. D. Lindley, Miss I. M. Smith, and Miss B. Stubbs for technical assistance at various times, and to Dr. M. G. Coyle, Miss E. Finch, Dr. F. J. Flint, Dr. H. A. Hartley, and Miss J. B. Price for assistance in the collection of normal urines.

\section{REFERENCES}

Appleby, J. I., Gibson, G., Norymberski, J. K., and Stubbs, R. D. (1955). Biochem. J., 60, 453.

Bayliss, R. I. S. (1952). Ibid., 52, 63.

Brooks, C. J. W., and Norymberski, J. K. (1953). Ibid., 55, 371.

Bush, I. E., and Sandberg, A. A. (1953). J. biol. Chem., 205, 783.

Diczfalusy, E., Plantin, L.-O., Birke, G., and Westman, A. (1955). Acta endocr. (Kbh.), 18, 356.

Eik-Nes, K., Sandberg, A. A., Migeon, C. J., Tyler, F. H., and Samuels, L. T. (1955). J. clin. Endocr., 15, 13.

Gibson, G., and Norymberski, J. K. (1954). Ann. rheum. Dis., 13, 59. Hernberg, C. A., and Lamberg, B. A. (1955). Acta endocr. (Kbh.), 18, 41.

Hill, S. R., jr., Reiss, R. S., Forsham, P. H., and Thorn, G. W. (1950). J. clin. Endocr., 10, 1375.

Hubble, D. V. (1955). Lancet, 1, 1.

Jailer, J. W. (1953). Bull. N.Y. Acad. Med., $29,377$.

Jepson, R. P., Jordan, A., and Levell, M. J. (1956). Brit. J. Surg., 43, 390 .

Levin, L., and Tyndale, H. H. (1937). Endocrinology, 21, 619.

Norymberski, J. K., Stubbs, R. D., and West, H. F. (1953). Lancet, 1, 1276.

Peters, J. H., Sieber, W. K., and Davis, N. (1955). J. clin. Endocr., 15, 182.

Schüller, E. (1956). Acta endocr. (Kbh.), $21,281$.

Statland, H., and Lerman, J. (1950). J. clin. Endocr., 10, 1401.

Thorn, G. W. (1953). Ibid., 13, 614. 